Article

\title{
Design of a ZnO/Poly(vinylidene fluoride) inverse opal film for photon localization-assisted full solar spectrum photocatalysis
}

\author{
Yukai Chen a,b,c, †, Yu Wang d,†, Jiaojiao Fang a,b,c, Baoying Dai a,b,c, Jiahui Kou a,b,c,*, Chunhua Lu a,b,c,\#, \\ Yuanjin Zhao d,\$ \\ a State Key Laboratory of Materials-Oriented Chemical Engineering, College of Materials Science and Engineering, Nanjing Tech University, Nanjing \\ 210009, Jiangsu, China \\ b Jiangsu Collaborative Innovation Center for Advanced Inorganic Function Composites, Nanjing Tech University, Nanjing 210009, Jiangsu, China \\ c Jiangsu National Synergetic Innovation Center for Advanced Materials (SICAM), Nanjing Tech University, Nanjing 210009, Jiangsu, China \\ d State Key Laboratory of Bioelectronics, School of Biological Science and Medical Engineering, Southeast University, Nanjing 210096, Jiangsu, China
}

\section{A R T I C L E I N F O}

\section{Article history:}

Received 23 February 2020

Accepted 10 April 2020

Published 5 January 2021

\section{Keywords:}

Photothermal catalysis

Photonic crystal

Inverse opal

Microreactor

$\mathrm{ZnO}$

\begin{abstract}
A B S T R A C T
Owing to its photonic band gap (PBG) and slow light effects, aniline black (AB)-poly(vinylidene fluoride) (PVDF) inverse opal (IO) photonic crystal (PC) was constructed to promote the utility of light and realize photothermal synergetic catalysis. As a highly efficient reaction platform with the capability of restricting heat, a microreactor was introduced to further amplify the photothermal effects of near infrared (NIR) radiation. The photocatalytic efficiency of ZnO/0.5AB-PVDF IO (Z0.5A) increases 1.63-fold compared to that of pure $\mathrm{ZnO}$ film under a full solar spectrum, indicating the effectiveness of synergetic promotion by slow light and photothermal effects. Moreover, a 5.85-fold increase is achieved by combining Z0.5A with a microreactor compared to the film in a beaker. The photon localization effect of PVDF IO was further exemplified by finite-difference time-domain (FDTD) calculations. In conclusion, photonic crystal-microreactor enhanced photothermal catalysis has immense potential for alleviating the deteriorating water environment.
\end{abstract}

(C) 2021, Dalian Institute of Chemical Physics, Chinese Academy of Sciences. Published by Elsevier B.V. All rights reserved.

\section{Introduction}

Providing tremendous hope in solving the crisis of diminishing fossil fuels and deteriorating water quality, photocatalysis has drawn researchers' attention since the ability of $\mathrm{TiO}_{2}$ to split water was first reported in 1972 [1-4]. By generating charge carriers in semiconductors, photocatalysis represents the viability of converting light energy into chemical energy [5-7]. Nevertheless, the low utilization rate of the full solar spectrum still poses a challenge to the commercialization of photocatalysis [8-11]. As is well-known, the full solar spectrum can be divided into three parts: ultraviolet with high energy, visible light, and near infrared (NIR) with photothermal effect [12-15]. Among them, UV light is equivalent to less than $5 \%$ of

\footnotetext{
* Corresponding author. E-mail: jhkou@njtech.edu.cn

\# Corresponding author. E-mail: chhlu@njtech.edu.cn

\$Corresponding author. E-mail: yjzhao@seu.edu.cn

† These authors contributed equally to this work.

This work was supported by the from National Natural Science Foundation of China (51872138), the Natural Science Foundation of Jiangsu Province (BK20181380, BK20150919), Jiangsu Province Postdoctoral Fund (1302096C), Key University Science Research Project of Jiangsu Province (15KJB430022), Qing Lan Project, Six Talent Peaks Project in Jiangsu Province (XCL-029) and Priority Academic Program Development of the Jiangsu Higher Education Institutions (PAPD) is gratefully acknowledged.

DOI: 10.1016/S1872-2067(20)63588-4 | http://www.sciencedirect.com/science/journal/18722067 | Chin. J. Catal., Vol. 42, No. 1, January 2021
} 
solar energy, while visible light and NIR are approximately $90 \%$ [16]. Thus, making use of visible light and NIR is an essential way to enhance photocatalytic efficiency. Aware of this, researchers discovered CdS [17-19], g- $\mathrm{C}_{3} \mathrm{~N}_{4}$ [20,21], and other highly efficient visible-light-absorbing photocatalysts $[22,23]$ to utilize visible light. Still, photons with wavelengths greater than $600 \mathrm{~nm}$ cannot be harnessed in the photocatalysis process. Upconversion, which converts photons with low energy to high energy photons, extends the absorption edge of photocatalysts to visible light and NIR regions. However, the low light conversion rate of upconversion makes it insufficient for providing enough energy for photocatalysis [24,25]. Despite its low photon energy, NIR radiation exhibits a powerful photothermal effect, which could raise reaction temperatures [26,27]. It is well-known that high temperatures activate photocatalysts and promote photocatalysis efficiency. Therefore, incorporating materials with good heat-absorbing abilities into photocatalysts and drawing upon visible light and infrared radiation which photocatalysts cannot absorb, could be a feasible solution to the problem [28-30].

Photonic crystal (PC) is a periodic structure that can confine light propagation to the spectral region called the photonic band gap (PBG) [31,32]. Among the different types of PC, opal and inverse opal (IO) structures have been widely researched due to their excellent optical performance. Owing to its PBG and slow light effects, PC structure has attracted great interest due to its potential application for improving light harvesting in photocatalysis [33-36]. The PBG effect can be described as light within the wavelength region of the PBG being forbidden from propagating in the PC on the grounds of Bragg diffraction and scattering $[37,38]$. Slow light effect means that the group velocity of photons would be reduced when trying to penetrate the PC structure, giving the photocatalyst more time to make use of the photons [39]. By means of the two effects, some $\mathrm{TiO}_{2}$-based PC structures have been prepared and showed obvious promotion of photocatalytic performance [40-42]. For the same reason, by adjusting the PBG to the region of NIR light, the absorption of NIR radiation can be strengthened so more heat can be produced to facilitate the reaction. Furthermore, besides constructing inverse opal photonic crystal (IOPC) directly by photocatalysts, another way, drawing upon the PC effect, is to prepare an IOPC skeleton followed by in-situ photocatalyst growth $[43,44]$. So far, no design like this has been used in the domain of photothermal synergetic catalysis.

Limited by the huge specific heat capacity of water, photothermal synergetic catalyses are scarcely applied in water purification, since water cannot be easily heated. Microreactors might be the silver bullet for this dilemma. Different from normal reaction cells, such as beakers, microreactors, with sizes limited at the level of micrometer or millimeter in at least one dimension, have great superiority in operating temperature. The volume of solution in a microreactor is approximately dozens of $\mu \mathrm{L}$, which means its temperature could be raised easily and rapidly, making a microreactor a wonderful cell for photothermal synergetic catalysis. Theoretically, the low Reynolds and Péclet numbers of microreactors confine flow patterns of solution and localize heat in their chamber, creating a posi- tive environment for photothermal catalysis [45]. Furthermore, microreactors could help solve two consequential problems of photocatalytic water purification: the mass transfer limit and energy penetration loss [46,47]. The low diameter or height of microreactors curtails the path length that dye molecules need to cross, facilitating mass transfer and making it easier to supplement their concentration around the surfaces of photocatalysts $[48,49]$. In comparison with normal reaction cells, their lower thickness of solution grants microreactors greater capability of absorbing photons due to the propagation path of the photons being reduced. Allowing for the preponderance of microreactors, photocatalysts have been grown in microreactors and vast improvements have been attained compared to normal reaction cells [50-52].

Herein, we report a facile route for constructing a highly ordered aniline black-poly(vinylidene fluoride) (AB-PVDF)-IOPC structure, in which ZnO nanoparticles were grown in situ. The composition of the reaction chamber and propagation avenue of light are shown in Scheme 1. As a polymer with great mechanical properties, PVDF has been widely used as a soft supporter for photocatalysts [53,54]. In addition, the feasibility of fabricating PVDF IOPC has been confirmed in previous works [55-57]. Showing good transmittance between 250 and $2500 \mathrm{~nm}, \mathrm{PVDF}$ is a reasonable candidate for the skeleton of IOPC. $\mathrm{AB}$, an organic photothermal compound which is miscible with PVDF, is a suitable choice as a photothermal conversion material in PVDF IOPC due to its impressive light absorption [58]. $\mathrm{ZnO}$ was chosen as the photocatalyst due to its non-toxicity, excellent stability, and fantastic reactivity $[59,60]$. The crystal phases, optical spectra, microstructure morphologies, operating temperatures, and photocatalytic performances of $\mathrm{ZnO} / \mathrm{AB}-\mathrm{PVDF}$ IO films were explored to clarify the enhancement features of this structure. By applying soft polymer-based IOPC film to photocatalytic water purification for the first time, this work might reveal a novel horizon for elevating the efficiency of photocatalysts.

\section{Experimental}

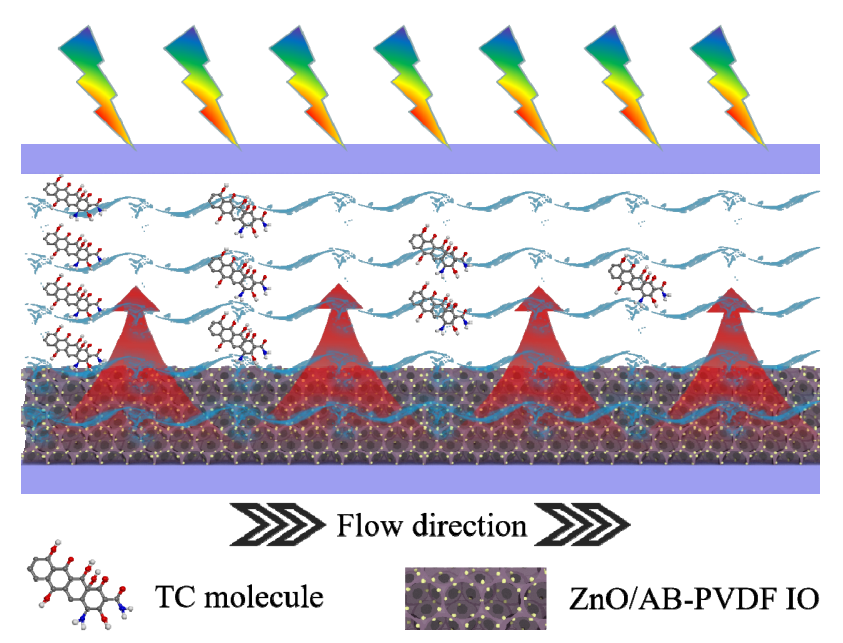

Scheme 1. Schematic illustration of photothermal catalysis by a $\mathrm{ZnO} / \mathrm{PVDF}$ IO film sealed in a microreactor. 


\subsection{Materials}

All the reagents were of analytical grade and used without further purification. Distilled water was used for the entire experiment. Monodisperse silica nanoparticles of different diameters were purchased from Nanjing Nanorainbow Biotechnology Co., Ltd. Poly(vinylidene fluoride) $\left(-\left(\mathrm{CH}_{2}-\mathrm{CF}_{2}\right)_{n^{-}}, 99.9 \%\right)$ was purchased from Aldrich Chemistry Co., Ltd. Aniline black $\left(\mathrm{C}_{22} \mathrm{H}_{14} \mathrm{~N}_{6} \mathrm{Na}_{2} \mathrm{O}_{9} \mathrm{~S}_{2}, 98.0 \%\right)$ was purchased from Sinopharm Chemical Reagent Co., Ltd. Zinc acetate dihydrate $\left(\mathrm{Zn}\left(\mathrm{CH}_{3} \mathrm{COO}\right)_{2} \cdot 2 \mathrm{H}_{2} \mathrm{O}, 99.0 \%\right)$ was purchased from Xilong Scientific Chemical Reagent Co., Ltd.

\subsection{Preparations}

A diagram of the preparation process of the $\mathrm{ZnO} / \mathrm{AB}-\mathrm{PVDF}$ IO films is illustrated in Fig. 1(a). A series of silica nanoparticles of different sizes $(247,369$, and $473 \mathrm{~nm}$ ) were dispersed in 20 wt $\%$ ethanol solution. Colloidal crystal templates were acquired through a vertical deposition method. A $40 \mu \mathrm{L}$ amount of the aforementioned solution was smoothly added onto a 70 $\times 25 \mathrm{~mm}$ glass slide. As the solvent gradually evaporated, the silica nanoparticles self-assembled into an orderly arrangement on the surface of the glass slide [61]. Then, the silica photonic crystals were calcined at $500{ }^{\circ} \mathrm{C}$ for $4 \mathrm{~h}$ to improve their mechanical strength. After that, $10 \mathrm{wt} \%$ PVDF/DMF solution with a certain ratio of $\mathrm{AB}$ was infiltrated into the opal template by capillary force, followed by drying at $60{ }^{\circ} \mathrm{C}$ under air for 0.5 h. The obtained films were soaked in $4 \mathrm{wt} \%$ hydrofluoric acid to etch the silica nanoparticles for AB-PVDF IO preparation.

$\mathrm{Zn}\left(\mathrm{CH}_{3} \mathrm{COO}\right)_{2}(5 \mathrm{~g})$ was dissolved in a mixed solution of 20 $\mathrm{mL}$ of deionized water and $5 \mathrm{~mL}$ of ethanol by stirring for 30 min. Then the AB-PVDF IO was immersed in the precursor solution for $4 \mathrm{~h}$ at room temperature after applying a hydrophilic treatment by plasma glow discharge. Afterwards, the AB-PVDF IO was dried under $\mathrm{N}_{2}$ flow before being kept in a oven at $70{ }^{\circ} \mathrm{C}$ for $24 \mathrm{~h}$ to form $\mathrm{ZnO}$ nanoparticles. Finally, the $\mathrm{ZnO} / \mathrm{AB}-\mathrm{PVDF}$ IO film was sealed in a microreactor of size $40 \times 25 \times 0.4 \mathrm{~mm}^{3}$ to carry out the photocatalytic tests. Samples were abbreviated as: $\mathrm{ZIO}, \mathrm{Z} 0.1 \mathrm{~A}, \mathrm{Z} 0.2 \mathrm{~A}, \mathrm{Z} 0.5 \mathrm{~A}$, and $\mathrm{Z} 1 \mathrm{~A}$ for the addition ratios of $\mathrm{AB}$ of $0,0.1 \%, 0.2 \%, 0.5 \%$, and $1 \%$, respectively. For the different template sizes, for Z0.5A for example, they were named Z0.5A-247, Z0.5A-369, and Z0.5A-473. The abbreviation ZF means $\mathrm{ZnO}$ film.

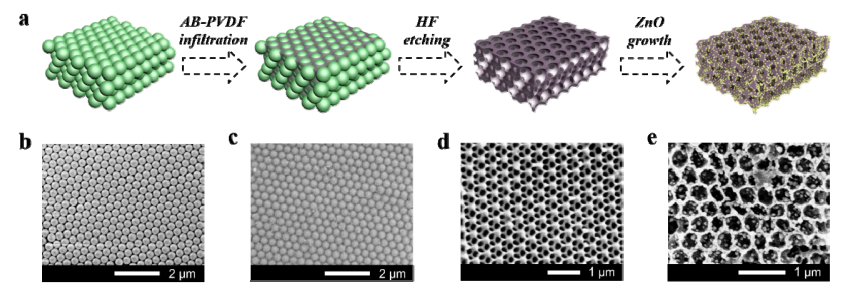

Fig. 1. (a) Preparation process illustration of the ZnO/PVDF IO film. FESEM images of the silica photonic crystal template (b), silica photonic crystal template after AB-PVDF infiltration (c), 0.5\%AB-PVDF IO film (d), and $\mathrm{ZnO} / 0.5 \% \mathrm{AB}-\mathrm{PVDF}$ IO film (e).

\subsection{Characterizations}

Crystal structures of the prepared samples were detected by an X-ray diffractometer (XRD; Rigaku SmartLab, Tokyo, Japan). Element statuses were examined by X-ray photoelectron spectroscopy (XPS; ESCALAB 250Xi; Thermo Fisher Scientific, Waltham, MA). Morphology was examined by scanning electron microscopy (SEM; SU-8010; Hitachi, Tokyo, Japan) and transmission electron microscopy (TEM; JEM 2100F; JEOL, Tokyo, Japan). Optical spectra were obtained using an ultraviolet-visible spectrophotometer (UV-vis; Agilent Technologies, Santa Clara, CA). Temperatures of the samples were measured with an infrared camera (FLIR-TG165).

The photocatalytic ability test system consisted of a $200 \mathrm{~W}$ Xe arc lamp (CEL-HXF300E; CEAULight, Beijing, China), $60 \mathrm{~mL}$ reaction cell, and microreactors containing the samples mentioned above. In a typical experiment, $50 \mathrm{~mL}$ of tetracycline (TC; $50 \mathrm{mg} / \mathrm{L}$ ) was drawn into a $50 \mathrm{~mL}$ syringe and injected into the microreactor by an injection pump with a flow speed of $20 \mathrm{~mL} / \mathrm{h}$. A comparison test was carried out by adding $50 \mathrm{~mL}$ of TC into a reaction cell and putting the $\mathrm{Z} 0.5 \mathrm{~A}$ film at the bottom. The Xe arc lamp was placed $20 \mathrm{~cm}$ above the reactor. After degradation, the solution was collected and tested by UV-vis spectrophotometry.

\section{Results and discussion}

\subsection{Characterization of the ZnO/AB-PVDF IO samples}

The morphologies of the silica photonic crystal template and 0.5\%AB-PVDF IO with and without $\mathrm{ZnO}$ nanoparticles were examined by field emission (FE) SEM (Fig. 1(b-e)). It is clear that the silica nanoparticles are of great uniformity and presented as a well-ordered periodic structure (Fig. 1(b)). As shown in Fig. 1(d), a highly-ordered 0.5\%AB-PVDF IO structure was obtained by removing the silica nanoparticles. Within the pores of the $0.5 \% \mathrm{AB}-\mathrm{PVDF} \mathrm{IO}, \mathrm{ZnO}$ nanoparticles can easily be seen (Fig. 1(e)). The energy dispersive spectroscopy (EDS) spectrum (Fig. S1) exhibits peaks for C, F, Zn, and O, which originate from the PVDF structure and $\mathrm{ZnO}$ nanoparticles.

XPS was employed to determine the composition of the Z0.5A film. As shown in Fig. S2, the Z0.5A sample is mainly composed of four elements: C, F, O, and Zn. Weak peaks for S, N, and $\mathrm{Na}$ can also be seen in the spectrum, which stem from the small addition amount of AB in the PVDF. Figure 2(a) displays four peaks for the $\mathrm{C} 1 s$ spectrum. The highest peak at $284.8 \mathrm{eV}$ can be attributed to $\mathrm{C}-\mathrm{C}$ bonds in the PVDF IO structure, and the second peak at $286.1 \mathrm{eV}$ could be due to surface $\mathrm{C}-\mathrm{OH}$ or $\mathrm{C}-\mathrm{O}-\mathrm{C}$ groups. The third peak at $288.8 \mathrm{eV}$ can be assigned to $\mathrm{C}=\mathrm{O}$ bonds in $\mathrm{AB}$, and the fourth peak at $290.7 \mathrm{eV}$ pertains to $\mathrm{C}-\mathrm{F}$ bonds in PVDF. The F 1 s spectrum (Fig. 2(b)) displays only one peak at $687.9 \mathrm{eV}$, which arises from $\mathrm{C}-\mathrm{F}$ bonds and corresponds to the peak at $290.7 \mathrm{eV}$ in the $\mathrm{C} 1 \mathrm{~s}$ spectrum. As for the $01 s$ spectrum (Fig. 2(c)), the first peak at $532 \mathrm{eV}$ belongs to lattice oxygens in the $\mathrm{ZnO}$ nanoparticles. The second peak at $532.8 \mathrm{eV}$ is attributed to oxygens of surface hydroxyl groups of $\mathrm{ZnO}$, while the third peak at $533.9 \mathrm{eV}$ is assigned to oxygens in 

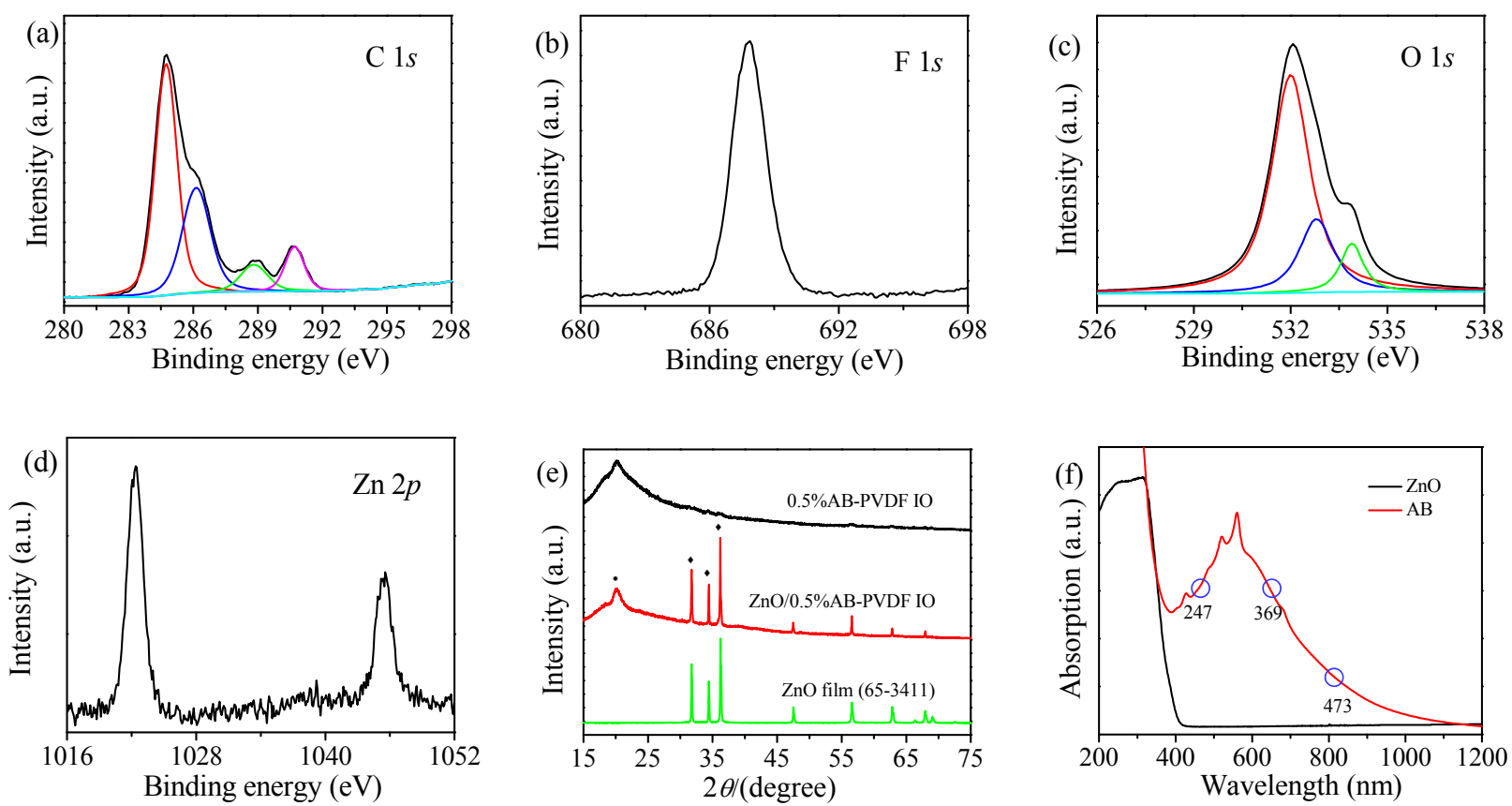

Fig. 2. XPS spectra of C $1 s$ (a), F $1 s$ (b), $01 s$ (c), and Zn $2 p$ (d) for the Z0.5A sample; (e) XRD spectra of the 0.5A, Z0.5A, and ZF samples; (f) absorption spectra of $\mathrm{ZnO}$ and $\mathrm{AB}$.

$\mathrm{C}-\mathrm{OH}$ corresponding to the $\mathrm{C} 1 \mathrm{~s}$ species at $286.1 \mathrm{eV}$. As shown in Fig. 2(d), two peaks at 1022.4 ( $\mathrm{Zn} \mathrm{2p} 3 / 2$ ) and 1045.6 (Zn $2 p_{1 / 2}$ ) eV correspond to the chemical element state of $\mathrm{Zn}^{2+}$ in the $\mathrm{ZnO}$ nanoparticles.

The phases of the prepared samples were determined by XRD measurements. The peaks (Fig. 2(e)) at $31.7^{\circ}, 34.4^{\circ}$, and $36.2^{\circ}$ can be assigned to (100), (002), and (101) planes of well-crystallized hexagonal ZnO (JCPDS No. 65-3411), respectively. A broad peak at $20.0^{\circ}$ can be seen in both the $0.5 \mathrm{~A}$ and Z0.5A samples, which belongs to the $\beta$-phase of PVDF. Based on the XRD and XPS spectra, formation of the PVDF film and ZnO
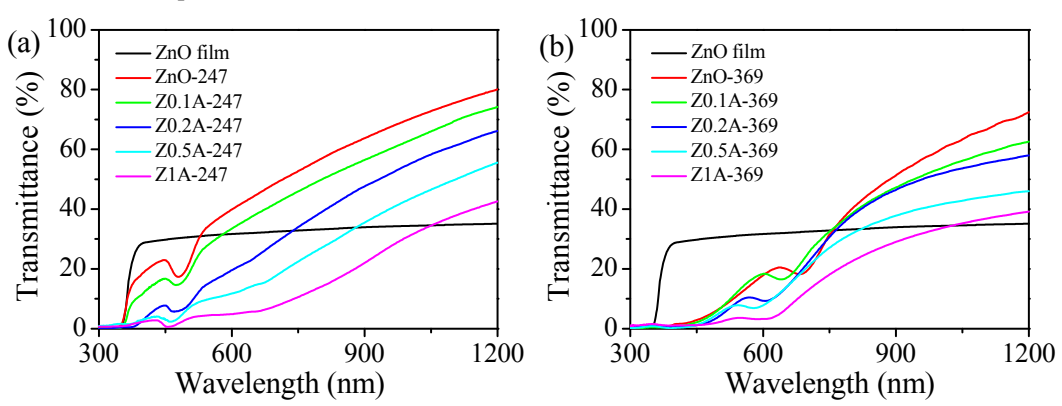

nanoparticles was supported.

The transmittance spectra of the silica photonic crystal templates are shown in Fig. S3. The PBGs of the silica PC centers are 555, 828, and $1065 \mathrm{~nm}$, respectively. The transmittance and specular reflection spectra of the ZnO/AB-PVDF IO films made from these templates were also tested as shown in Fig. 3. For the template with nanoparticles of size $369 \mathrm{~nm}$, the PBG of the pure ZnO/PVDF IO film center is $683 \mathrm{~nm}$. Increasing the amount of $\mathrm{AB}$, the PBGs of the ZnO/AB-PVDF IO films blue shift from 673 to $637 \mathrm{~nm}$ slightly. Nevertheless, even when the addition amount of $\mathrm{AB}$ was $1 \mathrm{wt} \%$, the PBG center was still

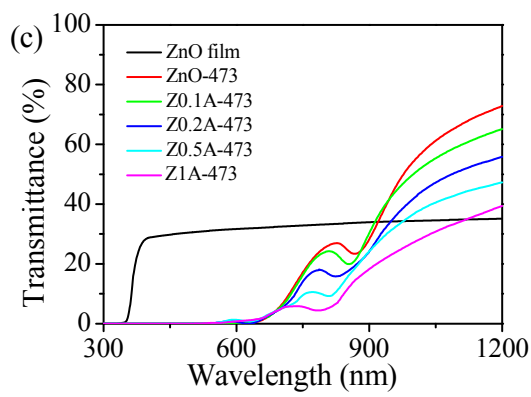

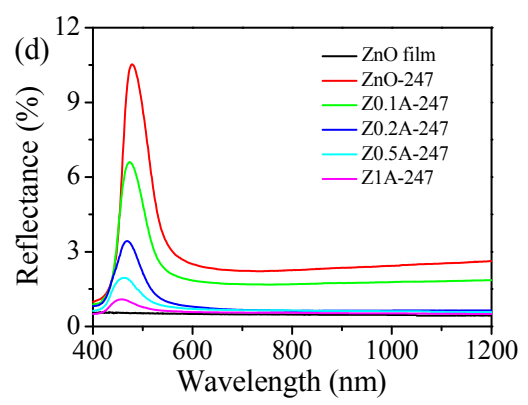
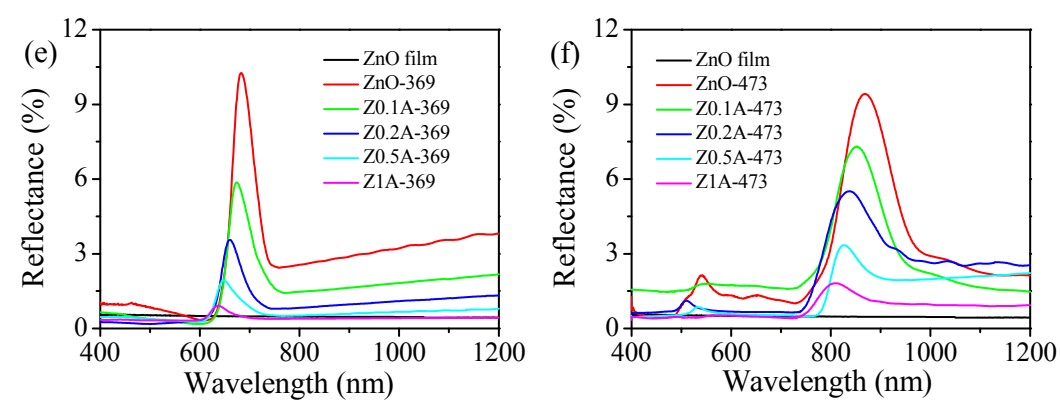

Fig. 3. Transmittance spectra of ZnO/AB-PVDF IO films made by silica templates of sizes: (a) $247 \mathrm{~nm}$; (b) $369 \mathrm{~nm}$; (c) $473 \mathrm{~nm}$. Specular reflection spectra of ZnO/AB-PVDF IO films made by silica templates of sizes: (d) $247 \mathrm{~nm}$; (e) $369 \mathrm{~nm}$; (f) $473 \mathrm{~nm}$. 
located in the red region (600-700 nm). Absorption of red light and infrared radiation (700-4000 $\mathrm{nm}$ ), well-known by researchers owing to their strong photothermal effects, could be enhanced by the band-gap effect of AB-PVDF IO to further strengthen the effect of photothermal catalysis. In addition, as the amount of $\mathrm{AB}$ increased, the transmittance and specular reflectance decreased gradually, implying absorption of light by AB. A similar phenomenon was also observed for the other two template sizes.

The PBGs of the Z0.5A samples with the three size pores were marked on the curve of the absorption spectrum of $A B$ (Fig. 2(f)). The PBGs of Z0.5A-247, Z0.5A-369, and Z0.5A-473 are 463,648 , and $825 \mathrm{~nm}$, respectively. None of these overlapped with the absorption peak or edge of $\mathrm{ZnO}$ (absorption edge $\approx 400 \mathrm{~nm}$ ) or TC (absorption peak $\approx 360 \mathrm{~nm}$ ), so enhancement of the PC due to the photocatalyst and dye can be excluded as predicted.

To investigate the photothermal effects of the ZnO/AB-PVDF IO samples, the operating temperatures of the microreactors for 60 min were recorded, as shown in Fig. 4(a). It is clear that of the different sizes of pores, the $\mathrm{ZnO} / \mathrm{AB}-\mathrm{PVDF}$ IO samples with a pore size of $369 \mathrm{~nm}$ showed the highest operating temperature. Reasons for this phenomenon can be found in Fig. 2(f). Taking the Z0.5A samples as an example, the absorption data for $\mathrm{AB}$ in the wavelengths of the PBGs of Z0.5A-247 and Z0.5A-369 are almost equal. However, the PBG of Z0.5A-247 is located in the region of blue light (400-480 $\mathrm{nm}$ ), which has nearly no photothermal effect. Absorption data for $\mathrm{AB}$ in the wavelengths of the PBG of Z0.5A-369 are far higher than those in the PBG of Z0.5A-473, which indicates more light absorption by the Z0.5A-369 sample. The pure film, with no PC structure to enhance absorption, exhibits the lowest temperature increase as predicted. A $14.7^{\circ} \mathrm{C}$ temperature ris- ing gap can be observed between Z0.5A-369 and ZF. To fully display the excellent temperature rising effect of this structure, the temperatures of the ZnO/PVDF IO samples irradiated by a xenon lamp for $2 \mathrm{~min}$ in air were examined (Fig. 4(b)). The data shows that Z0.5A-369 could gain a $26.8{ }^{\circ} \mathrm{C}$ temperature rising gap versus ZF0.5A in only $2 \mathrm{~min}$.

\subsection{Photocatalytic performance of the ZnO/AB-PVDF IO samples}

Photocatalysis tests were carried out in microreactors. Increases of $69.1 \%, 69.4 \%$, and $70.1 \%$ can be seen for ZIO-247, ZIO-369, and ZIO-473 versus ZF film, respectively, which can be ascribed to the porous structure of PVDF IO (Fig. 5(a)). As for the influence of the addition amount of $\mathrm{AB}, \mathrm{ZnO} / \mathrm{AB}-\mathrm{PVDF}$ IO samples with a pore size of $369 \mathrm{~nm}$ were analyzed as an example. The increases in the photocatalytic activities are $10.0 \%$, $24.5 \%, 55.2 \%$, and $47.9 \%$ for $\mathrm{Z} 0.1 \mathrm{~A}, \mathrm{Z} 0.2 \mathrm{~A}, \mathrm{Z0.5A}$, and $\mathrm{Z1A}$ versus $\mathrm{ZIO}$, respectively. With the addition amount of $\mathrm{AB}$ increasing from $0.1 \%$ to $0.5 \%$, more heat was produced due to the photothermal conversion ability of $\mathrm{AB}$, promoting the photocatalytic performance of the ZnO/PVDF IO film. Nonetheless, when the addition amount of $A B$ reached $1 \%$, part of the ultraviolet spectrum will be absorbed by $A B$, which might reduce the utilization of light by $\mathrm{ZnO}$ and undermine the activity of the film. Cyclic experiments of Z0.5A-369 were carried out under the same conditions. The photocatalytic degradation capability of TC over Z0.5A-369 is well maintained after ten runs (Fig. 5(b)), which exemplifies both the good photocatalytic stability of the $\mathrm{ZnO}$ nanoparticles and mechanical properties of the PVDF structure.

Photoinduced electron-hole pairs are the main reactive species in photocatalytic reactions. They are excited by photons
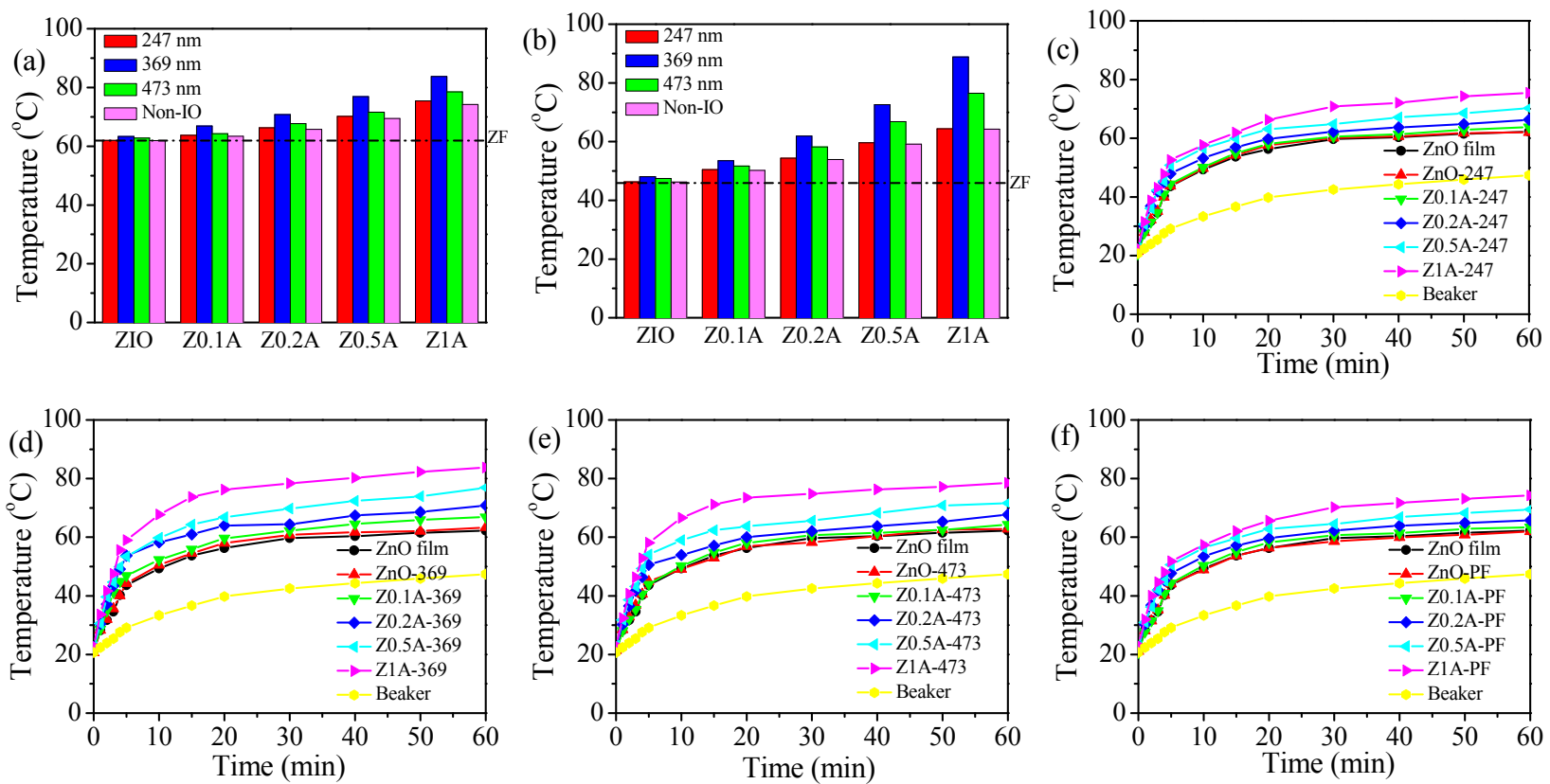

Fig. 4. Temperatures of the ZnO/AB-PVDF IO samples irradiated by xenon lamp for 60 min in microreactors (a) and 2 min in air (b). Temperature curves of Zn0/PVDF IO samples irradiated by xenon lamp in microreactors of pore size = 247 (c), 369 (d), 473 (e), and pure film without PC structure (f). 

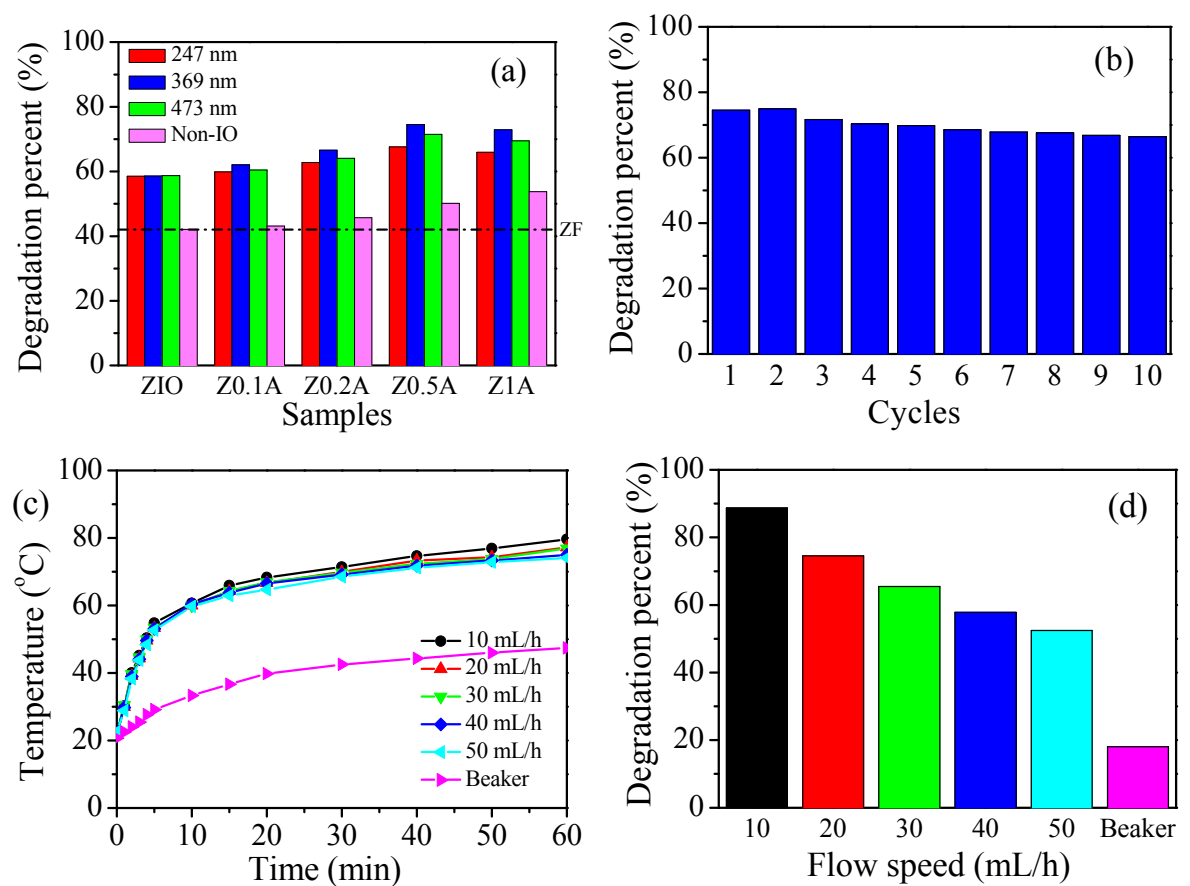

Fig. 5. (a) Photocatalytic performance of ZnO/AB-PVDF IO samples for TC degradation under simulated solar light irradiation for 1 h; (b) Cyclic degradation efficiency of TC over Z0.5A-369; Operating temperature curve (c) and photocatalytic performance (d) of Z0.5A-369 for TC degradation under different flow speeds.

with high energy and produce $\mathrm{O}_{2} \cdot-$ and $\bullet \mathrm{OH}$ to react with target molecules. In the process of photothermal synergetic catalysis, heat does not directly excite electron-hole pairs because its energy is too low for the bandgap of photocatalysts, such as $\mathrm{ZnO}(3.37 \mathrm{eV})$ used in this work. However, heat can endow high kinetic energy to photogenerated electron-hole pairs that are already excited by UV light. Thus, the mobility of these photogenerated carriers is improved. In addition, higher temperatures also activate reactant molecules, accelerating their movement and increasing their collision odds with photocatalysts, eventually leading to enhanced photothermal catalytic performance.

Flow speed, a significant factor for photocatalysis in microreactors, was studied by testing the photocatalytic performance of Z0.5A-369 for TC degradation under different flow speeds. The temperature curves (Fig. 5(c)) show operating temperature was slightly higher when flow speed was lower, which can be explained by lower flow speeds carrying less heat out of the microreactor. Still, the temperatures for $10-50 \mathrm{~mL} / \mathrm{h}$ were very close to each other; therefore, it can be considered that temperature has little influence on photocatalytic performance under different flow speeds. Fig. 5(d) shows the degradation rate of TC decreased with increasing flow speed, which stems from the residence time being inversely proportional to flow speed [62]. The residence times corresponding to the flow speeds of $10,20,30,40$, and $50 \mathrm{~mL} / \mathrm{h}$ are $0.278,0.556,0.833$, 1.111 , and $1.389 \mathrm{~mm} / \mathrm{s}$, respectively.

Compared to the film in the beaker, the film sealed in the microreactor with a flow speed of $20 \mathrm{~mL} / \mathrm{h}$ had a 5.85 -fold increase in photocatalytic performance. Reasons for this promotion can be attributed to the following four points. Firstly, light only needs to penetrate a solution thickness of $400 \mu \mathrm{m}$ in the microreactor compared to $2.5 \mathrm{~cm}$ in the beaker, which means more light can be absorbed by the photocatalyst in the microreactor. Secondly, the low thickness of the microreactor reduces the diffusion distances of molecules significantly, resulting in a rapid supplement of molecules to the surface of the photocatalyst via concentration gradient. Thirdly, flow of solution carries reaction products away, refreshing the active sites of the photocatalyst. Last but not least, the flow pattern in the microreactor is a typical laminar flow since its Reynolds number is far less than 2000, which means a low Péclet number, contributing to a thermal localization effect in the microreactor [45]. Furthermore, the small volume of solution makes the microreactor more prone to higher temperature rises under the same light irradiation and eventually increases the photocatalytic performance.

\subsection{Discussion of the mechanism}

To further demonstrate the enhancement of photocatalysis by the IO structure, transmittance and specular reflection spectra as well as electric field distributions of PVDF IO were calculated by finite-difference time-domain (FDTD) method [63]. The PBG of PIO-369 is centered at approximately $700 \mathrm{~nm}$ (Figs. S5(a) and (b)), which almost overlaps with the PBG of the experimental sample. As seen in Fig. 6(d), the electric field distribution is uniform, and photons are localized in the gaps between PVDF IO structures due to the localization effect of the $\mathrm{PC}$, giving rise to the augmentation of light absorption by the photocatalysts and AB in the PVDF IO structure.

The mechanism of photocatalytic degradation by the ZnO/AB-PVDF IO films is proposed and represented in Fig. 6. While under irradiation by the xenon lamp, $\mathrm{ZnO}$ nanoparticles 
a

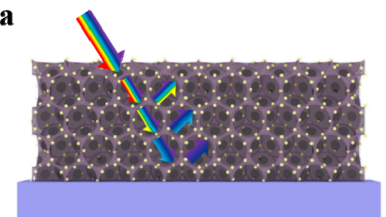

c

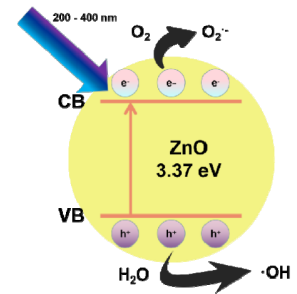

b

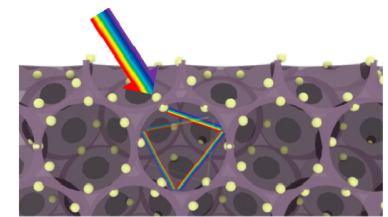

d

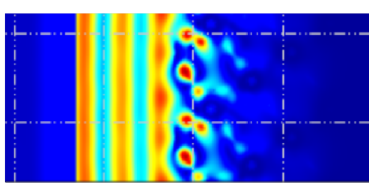

Fig. 6. Illustrations of: (a) the light propagation pathway in ZnO/AB-PVDF IO, (b) light localization effect of ZnO/AB-PVDF IO, and (c) photocatalysis process of $\mathrm{ZnO}$ nanoparticles. (d) Electric field distribution of ZnO/PIO-369 calculated by FDTD.

on the pore surface of the AB-PVDF IO absorb ultraviolet light preferentially. Photons left unabsorbed, either ultraviolet or light of lower frequency, will be reflected to nearby $\mathrm{ZnO}$ nanoparticles or pass through the AB-PVDF IO structure and eventually be absorbed by $\mathrm{AB}$ to produce heat. As for the $\mathrm{ZnO}$ nanoparticles, the photons excite electrons to the conduction band and leave holes in the valence band. Then the photogenerated electrons reduce dissolved oxygen to produce $\mathrm{O}_{2}{ }^{--}\left(\mathrm{O}_{2}+\right.$ $\mathrm{e} \rightarrow \mathrm{O}_{2}{ }^{-}$), while holes oxidize $\mathrm{H}_{2} \mathrm{O}$ to create $\cdot \mathrm{OH}\left(\mathrm{H}_{2} \mathrm{O}+\mathrm{h}^{+} \rightarrow\right.$ $\left.\cdot \mathrm{OH}+\mathrm{H}^{+}\right) . \mathrm{O}_{2} \cdot-$ and $\bullet \mathrm{OH}$ eventually react with $\mathrm{TC}$, decomposing it into smaller molecules.

\section{Conclusions}

A three-dimensional, highly ordered ZnO/AB-PVDF IO structure was fabricated via a facile self-assembly and hydrothermal reaction approach. ZnO nanoparticles were grown on the pore surface of PVDF IO to increase light utilization, while $\mathrm{AB}$ was added into the PVDF structure to enhance the photothermal effect. Enhancement of the photothermal effect via the slow light effect of the IOPC structure showed the operating temperature had a $21.6{ }^{\circ} \mathrm{C}$ temperature rising gap for $\mathrm{ZnO} / 0.5 \% \mathrm{AB}-\mathrm{PVDF}$ IO versus $\mathrm{ZnO} / 0.5 \% \mathrm{AB}-\mathrm{PVDF}$ film. Thus, $\mathrm{ZnO} / 0.5 \% \mathrm{AB}-\mathrm{PVDF}$ IO represents a 1.63 -fold increase of TC degradation compared to that of $\mathrm{ZnO}$ film. Moreover, the film sealed in the microreactor with a flow speed of $20 \mathrm{~mL} / \mathrm{h}$ saw a 5.85-fold increase compared to the film in the beaker, justifying the preeminent heat localization effect of the microreactor. Additionally, the good photostability of the ZnO/PVDF IO samples was corroborated by a cyclic degradation test. With the assistance of FDTD calculations, the electric field distribution of $\mathrm{ZnO} / \mathrm{PIO}$ was simulated, and the localization effect of photons was clearly seen, supporting the promotion of photocatalytic performance by the IOPC structure. This work demonstrates a new design for photothermal synergetic catalysis by combining ZnO nanoparticles with AB-PVDF IOPC, proposing a novel avenue for utilization of the solar light spectrum.

\section{References}

[1] X. Xu, F. Luo, W. Tang, J. Hu, H. Zeng, Y. Zhou, Adv. Funct. Mater., 2018, 28, 1804055.

[2] M. B. Gawande, A. Goswami, T. Asefa, H. Guo, A. V. Biradar, D. Peng, R. Zboril, R. S. Varma, Chem. Soc. Rev., 2015, 44, 7540-7590.

[3] D. Wu, S. Hu, H. Xue, X. Hou, H. Du, G. Xu, Y. Yuan, J. Mater. Chem. A, 2019, 7, 20223-20228.

[4] J. Kou, C. Lu, J. Wang, Y. Chen, Z. Xu, R. S. Varma, Chem. Rev., 2017, $117,1445-1514$.

[5] F. He, A. Meng, B. Cheng, W. Ho, J. Yu, Chin. J. Catal., 2020, 41, 9-20.

[6] Z. Ren, X. Liu, Z. Zhuge, Y. Gong, C. Q. Sun, Chin. J. Catal., 2020, 41, 180-187.

[7] D. Li, S. Li, Y. Li, Y. Huang, C. Wang, X. Zhang, Y. Liu, Chin. J. Catal., 2020, 41, 154-160.

[8] K. Qi, W. Lv, I. Khan, S. Liu, Chin. J. Catal., 2020, 41, 114-121.

[9] K. Qi, Y. Xie, R. Wang, S. Liu, Z. Zhao, Appl. Surf. Sci., 2019, 466, 847-853.

[10] K. Qi, B. Cheng, J. Yu, W. Ho, Chin. J. Catal., 2017, 38, 1936-1955.

[11] K. Qi, B. Cheng, J. Yu, W. Ho, J. Alloys Compd., 2017, 727, 792-820.

[12] S. Chen, J. Yu, J. Zhang, J. CO Util., 2018, 24, 548-554.

[13] N. Nie, L. Zhang, J. Fu, B. Cheng, J. Yu, Appl. Surf. Sci., 2018, 441, 12-22.

[14] S. Wang, B. Zhu, M. Liu, L. Zhang, J. Yu, M. Zhou, Appl. Catal. B, 2019, 243, 19-26.

[15] S. Wang, P. Kuang, B. Cheng, J. Yu, C. Jiang, J. Alloys Compd., 2018, 741, 622-632.

[16] X. Wang, F. Wang, Y. Sang, H. Liu, Adv. Energy Mater., 2017, 7, UNSP1700473.

[17] D. S. Patil, S. A. Pawar, J. C. Shin, Chem. Eng. J., 2018, 335, 693-702.

[18] B. Chong, L. Chen, D. Han, L. Wang, L. Feng, Q. Li, C. Li, W. Wang, Chin. J. Catal., 2019, 40, 959-968.

[19] T. Wang, X. Liu, Q. Men, C. Ma, Y. Liu, W. Ma, Z. Liu, M. Wei, C. Li, Y. Yan, Chin. J. Catal., 2019, 40, 886-894.

[20] P. Niu, L. Zhang, G. Liu, H. Cheng, Adv. Funct. Mater., 2012, 22, 4763-4770.

[21] J. Xing, F. Lin, L. Huang, Y. Si, Y. Wang, L. Jiao, Chin. J. Catal., 2019, 40, 1352-1359.

[22] G. Li, Q. Shen, Z. Yang, S. Kou, F. Zhang, W. Zhang, H. Guo, Y. Du, Appl. Catal. B, 2019, 248, 115-119.

[23] Y. Yang, S. Wang, Y. Jiao, Z. Wang, M. Xiao, A. Du, Y. Li, J. Wang, L. Wang, Adv. Funct. Mater., 2018, 28, UNSP1805698.

[24] S. Wu, H. I. Butt, Adv. Mater., 2016, 28, 1208-1226.

[25] M. Zhao, W. Wang, C. Huang, W. Dong, Y. Wang, S. Cheng, H. Wang, H. Qian, Chin. J. Catal., 2018, 39, 1240-1248.

[26] C. K. N. Peh, M. Gao, G. W. Ho, J. Mater. Chem. A, 2015, 3, 19360-19367.

[27] A. Castedo, A. Casanovas, I. Angurell, L. Soler, J. Llorca, Fuel, 2018, 222, 327-333.

[28] Y. Zhao, G. I. N. Waterhouse, G. Chen, X. Xiong, L. Z. Wu, C. H. Tung, T. Zhang, Chem. Soc. Rev., 2019, 48, 1972-2010.

[29] X. Meng, L. Liu, S. Ouyang, H. Xu, D. Wang, N. Zhao, J. Ye, Adv. Mater., 2016, 28, 6781-6803.

[30] G. Wen, J. Diao, S. Wu, W. Yang, R. Schoegl, D. S. Su, ACS Catal., 2015, 5, 3600-3608.

[31] L. Zhang, R. Gogna, H. Deng, W. Burg, E. Tutuc, Nat. Commun., 2018, 9, 713.

[32] X. Zheng, Y. Yang, S. Chen, L. Zhang, Chin. J. Catal., 2018, 39, 379-389.

[33] Y. Zhang, J. Zhou, W. Cai, J. Zhou, Z. Li, Appl. Surf. Sci., 2018, 430, 549-560.

[34] C. Zhang, P. Zhao, S. Liu, K. Yu, Chin. J. Catal., 2019, 40, 1324-1338. 


\title{
Graphical Abstract
}

Chin. J. Catal., 2021, 42: 184-192 doi: 10.1016/S1872-2067(20)63588-4

Design of a ZnO/Poly(vinylidene fluoride) inverse opal film for photon localization-assisted full solar spectrum photocatalysis

Yukai Chen, Yu Wang, Jiaojiao Fang, Baoying Dai, Jiahui Kou *, Chunhua Lu*, Yuanjin Zhao *

Nanjing Tech University; Southeast University

ZnO/PVDF inverse opal film was prepared to reach photothermal synergetic catalysis in the microreactor. By utilizing photon localization effect and slow light effect, the photocatalytic performance was greatly enhanced.

[35] J. Low, L. Zhang, B. Zhu, Z. Liu, J. Yu, ACS Sustain. Chem. Eng., 2018, 6, 15653-15661.

[36] S. Meng, D. Li, X. Zheng, J. Wang, J. Chen, J. Fang, Y. Shao, X. Fu, J. Mater. Chem. A, 2013, 1, 2744.

[37] P. Chen, I. W. Jung, D. A. Walko, Z. Li, Y. Gao, G. K. Shenoy, D. Lopez, J. Wang, Nat. Commun., 2019, 10, 1158.

[38] Y. Wu, K. Zhang, B. Yang, Adv. Opt. Mater., 2019, 7, 1800980.

[39] M. Curti, J. Schneider, D. W. Bahnemann, C. B. Mendive, J. Phys. Chem. Lett., 2015, 6, 3903-3910.

[40] X. Zheng, D. Li, X. Li, J. Chen, C. Cao, J. Fang, J. Wang, Y. He, Y. Zheng, Appl. Catal. B, 2015, 168, 408-415.

[41] Z. Geng, Y. Zhang, X. Yuan, M. Huo, Y. Zhao, Y. Lu, Y. Qiu, J. Alloys Compd., 2015, 644, 734-741.

[42] S. L. Chen, A. J. Wang, C. Dai, J. B. Benziger, X. C. Liu, Chem. Eng. J., 2014, 249, 48-53.

[43] K. Y. Yoon, J. S. Lee, K. Kim, C. H. Bak, S. I. Kim, J. B. Kim, J. H. Jang, ACS Appl. Mater. Interfaces, 2014, 6, 22634-22639.

[44] Y. Song, N. Li, D. Chen, Q. Xu, H. Li, J. He, J. Lu, Appl. Catal. B, 2018, 238, 255-262.

[45] K. S. Elvira, X. C. I. Solvas, R. C. R. Wootton, A. J. DeMello, Nat. Chem., 2013, 5, 905-915.

[46] J. Parmar, S. Jang, L. Soler, D. Kim, S. Sanchez, Lab Chip, 2015, 15, 2352-2356.

[47] N. Wang, X. Zhang, Y. Wang, W. Yu, H. L. W. Chan, Lab Chip, 2014, $14,1074-1082$.

[48] A. Yusuf, C. Garlisi, G. Palmisano, Catal. Today, 2018, 315, 79-92.

[49] M. Liu, X. Zhu, R. Chen, Q. Liao, D. Ye, B. Zhang, J. Liu, G. Chen, K. Wang, Chem. Eng. J., 2018, 354, 35-41.

[50] N. Wang, X. Zhang, B. Chen, W. Song, N. Y. Chan, H. L. W. Chan, Lab
Chip, 2012, 12, 3983-3990.

[51] Z. Wei, Y. Chen, P. Lin, Q. Yan, Y. Fan, Z. Cheng, J. Mater. Sci., 2019, $54,6841-6852$.

[52] M. Krivec, K. Zagar, L. Suhadolnik, M. Ceh, G. Drazic, ACS Appl. Mater. Interfaces, 2013, 5, 9088-9094.

[53] B. Dai, Y. Yu, Y. Chen, H. Huang, C. Lu, J. Kou, Y. Zhao, Z. Xu, $A d v$. Funct. Mater., 2019, 29, UNSP1807934.

[54] M. Kitsara, A. Blanquer, G. Murillo, V. Humblot, S. De Braganca Vieira, C. Nogues, E. Ibanez, J. Esteve, L. Barrios, Nanoscale, 2019, 11, 8906-8917.

[55] Y. Shang, Z. Chen, F. Fu, L. Sun, C. Shao, W. Jin, H. Liu, Y. Zhao, ACS Nano, 2019, 13, 796-802.

[56] M. Quan, B. Yang, J. Wang, H. Yu, X. Cao, ACS Appl. Mater. Interfaces, 2018, 10, 4243-4249.

[57] N. Wang, Y. Ma, J. Chen, C. Chen, H. San, J. Chen, Z. Cheng, Nanoscale, 2018, 10, 13028-13036.

[58] L. Fang, T. Fang, X. Liu, S. Chen, C. Lu, Z. Xu, Macromol. Mater. Eng., 2016, 301, 1111-1120.

[59] L. Lee, J. Hwang, J. W. Jung, J. Kim, H. Lee, S. Heo, M. Yoon, S. Choi, V. L. Nguyen, J. Park, J. W. Jeong, J. Kim, K. R. Kim, D. H. Kim, S. Im, B. H. Lee, K. Cho, M. M. Sung, Nat. Commun., 2019, 10, 1998.

[60] F. Peng, Q. Zhou, C. Lu, Y. Ni, J. Kou, Z. Xu, Appl. Surf. Sci., 2017, 394, 115-124.

[61] H. Xu, Y. F. Lu, J. X. Xiang, M. K. Zhang, Y. J. Zhao, Z. Y. Xie, Z. Z. Gu, Nanoscale, 2018, 10, 2090-2098.

[62] L. Lei, N. Wang, X. M. Zhang, Q. Tai, D. P. Tsai, H. L. W. Chan, Biomicrofluidics, 2010, 4, 043004.

[63] C. Zhu, W. Zhou, J. Fang, Y. Ni, L. Fang, C. Lu, Z. Xu, Z. Kang, J. Alloys Compd., 2018, 741, 337-347.

\section{利用局域光效应增强全光谱光催化的ZnO/PVDF反蛋白石结构薄膜}

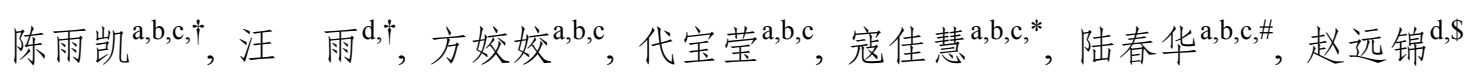 \\ a南京工业大学材料科学与工程学院, 江苏南京 210009 \\ b 南京工业大学江苏省先进无机功能复合材料协同创新中心，江苏南京210009 \\ c南京工业大学江苏省先进材料协同创新中心, 江苏南京210009 \\ $\mathrm{d}$ 东南大学生物科学与医学工程学院, 生物电子国家重点实验室, 江苏南京 210096
}

摘要: 随着环境污染与能源危机的问题日益严重, 利用清洁能源太阳能的光催化技术得到了研究者的广泛关注. 然而, 半 导体光催化剂的带隙严重限制了其利用整个太阳光谱的能力. 尽管通过能带工程、上转换等技术, 已经有部分可见光可以 
被利用, 但其本身的效率却并不高. 太阳光谱中的近红外光有着显著的光热效应, 可提高光催化反应的温度, 促进光生载 流子的分离, 进而提升光催化的效果. 光子晶体是一种周期性结构, 通过调节其折射率以及孔径大小, 可以对不同波段的 光实现增强吸收或反射的效果. 人们已制备了二氧化钛的反蛋白石结构用于光催化降解污染物, 其光催化效率明显提高. 但是, 通过利用反蛋白石结构光子晶体增强近红外光的吸收, 进而实现全光谱利用的光热协同催化目前还未有报道.

本文以二氧化硅单分散微球为模板, 制备了以苯胺黑-聚偏氟乙烯为基底、氧化锌为光催化剂的反蛋白石结构光子晶 体薄膜, 采用扫描电镜、XRD和XPS等技术表征了薄膜的结构, 并通过透射光谱与镜面反射光谱验证了苯胺黑的加入可增 强全光谱的利用率. 结果发现, 当苯胺黑掺量为 $0.5 \%$ 时, 微反应器中的薄膜温度在 $60 \mathrm{~min}$ 内上升了 $13.6^{\circ} \mathrm{C}$, 而空气中的薄膜 温度在 $2 \mathrm{~min}$ 内升了 $24.5^{\circ} \mathrm{C}$, 表明苯胺黑在近红外光生热中起着重要作用. 对比普通薄膜, Z0.5A-369在微反应器与空气中 的温度分别提升了 14.7 和 $26.8^{\circ} \mathrm{C}$, 证实了光子晶体对于光谱吸收的增强效应. 就光催化性能来看, Z0.5A-369比普通薄膜的 效率提高了 1.63 倍, 而微反应器也比普通反应器提升了 5.85 倍. 可见, 薄膜和反应器的设计实现了协同催化.

光热协同光催化发现, 利用近红外光的光热效应来提高光催化反应过程中的温度可有效促进光催化反应, 是一种高效 利用太阳光谱的方法. 光子晶体因其多孔结构、高比表面积、限光效应和慢光效应而增强了对光的吸收, 进一步提高了光 催化效率. 另外, 微反应器通过其局域的热效应和缩短的传质路径有效地增加了反应速率.

关键词: 光催化; 光子晶体; 反蛋白石结构; 微反应器; 氧化锌

收稿日期: 2020-02-23. 接受日期: 2020-04-10. 出版日期: 2021-01-05.

*通讯联系人. 电子信箱: jhkou@njtech.edu.cn

\#通讯联系人. 电子信箱: chhlu@njtech.edu.cn

通讯联系人. 电子信箱: yjzhao@seu.edu.cn

†共同第一作者.

基金来源：国家自然科学基金(51872138); 江苏省自然科学基金(BK20181380，BK20150919); 江苏省博士后基金(1302096C); 江 苏省重点大学科研项目(15KJB430022); 江苏省六大人才高峰工程(XCL-029); 江苏高校优势学科建设工程项目.

本文的电子版全文由Elsevier出版社在ScienceDirect上出版(http://www.sciencedirect.com/science/journal/18722067). 